\title{
DEMOTIVATION OF MEDICAL STAFF IN THE SELECTED HEALTH FACILITY IN SLOVAKIA
}

\author{
Stanislav Szabo', Bohuslava Mihalčová2, Jozef Lukáčč \\ Peter Gallo4, Veronika Čabinová, Iveta Vajdová ${ }^{6}$
}

\footnotetext{
1 Technical University of Košice, Faculty of Aeronautics, Department of Air Traffic Management, Slovakia, ORCID: 0000-0001-6174-5784, stanislav.szabo@tuke.sk;

2 University of Economics in Bratislava, Faculty of Business Economy with Seat in Košice, Slovakia, bohuslava.mihalcova@euke.sk;

3 University of Economics in Bratislava, Faculty of Business Economy with Seat in Košice, Slovakia, jozef.lukac@euke.sk;

4 University of Prešov in Prešov, Faculty of Management, Department of Management, Slovakia, ORCID: 0000-00015193-1997, peter.gallo.1@unipo.sk;

5 University of Prešov in Prešov, Faculty of Management, Department of Finance, Slovakia, ORCID: 0000-00034367-3590, veronika.cabinova@smail.unipo.sk;

6 Technical University of Košice, Faculty of Aeronautics, Department of Air Traffic Management, Slovakia, ORCID: 0000-0002-1231-8492, iveta.vajdova@tuke.sk.
}

\begin{abstract}
The biggest challenges for today's businesses and facilities in ministries (health, education, defence, police, etc.) are to constantly increase their effectiveness. The quality and efficiency of each business are above all quality employees. They should be as satisfied and motivated as possible to their work performance. This requires careful and funded leadership by properly prepared and carefully considered managers. Providing excellent employee work performance is beneficial to the enterprise/organization and workers themselves. Nowadays, when employees are an integral part of a knowledge-based business/organization, there is a progress that cannot be achieved without development of the workforce. Although educated people work in the healthcare facility under investigation, it is not always possible to achieve a synergy effect based on excellent work performance and successful system management of the given healthcare facility. Managerial readiness and knowledge of factors affecting employee satisfaction and motivation enables them to prepare an appropriate incentive program that can influence the behaviour of individuals or workgroups towards to develop and effectively use the potential of employees, their responsible and quality work, considering their personal goals, and also the interest in the entire facility. Motivation/demotivation of healthcare personnel are frequently discussed issue in relation to healthcare policy making and overall health performance. The quality of health care and the performance of healthcare providers depend not only on the level of education, but also on the willingness and motivation of healthcare professionals. Even in a relatively stable environment, it is necessary to examine what contributes to the motivation of individual workers and what their behavioural patterns are. While motivation is generally paid great attention, in the healthcare system, research is mainly carried out on its performance and relatively few studies relate only to the field of motivation of healthcare professionals. The authors' ambition is to present research on this topic and to introduce some measures that could contribute to improving the motivation system of healthcare personnel in Slovakia. In a sense, we have tried to briefly compare the similarity of the system of healthcare motivation in Slovakia to systems in selected, mainly developed countries.
\end{abstract}

Keywords: Factors of demotivation, motivation, health sector, health facility, Slovakia.

JEL Classification: G34, M12.

APA Style Citation: Szabo, S., Mihalčová, B., Lukáč, J., Gallo, P., Čabinová, V., \& Vajdová, I. (2020). Demotivation of Medical Staff in the Selected Health Facility in Slovakia. E\&M Economics and Management, 23(2), 83-95. https://doi.org/10.15240/tul/001/2020-2-006 


\section{Introduction}

In the context of the research on human behaviour, the issue we deal with is the reason why a people's message is precisely that, and not another one, what forces them to act as they do. Is it an external compulsion - e.g. to escape from danger, or that they want to achieve something - to satisfy some of their needs, interests in hobbies, or because they consider it right and moral? Can a person behave in a way that has no cause, or reason?

Although we distinguish between involuntary and voluntary behaviour, human behaviour in the work process is largely influenced by the will, the desire that results from the impact of several motives. The concept of motivation is the internal process, the process of psychological causes of human behaviour. These causes are motives, internal presuppositions, and internal impulses leading to certain target behaviour. The process of motivation is thus the process of activating internal assumptions, guiding human action to a certain goal of their pursuit (Nakonečný, 1992). Motivation can be defined as processes that account for an individual's intensity, direction and persistence of effort toward attaining a goal (Robbins, 2001).

Motivation as a process avoids any social or entrepreneurial sphere and is a phenomenon whose research is continuing. For several years we have witnessed the dissatisfaction and demotivation of workers in various sectors of the national economy, especially healthcare professionals. Healthcare professionals leave and work abroad, doctors and nurses are missing. There are also alarming numbers of emergency doctors that are steadily decreasing. In the past six months, other 26 rescue stations have finished. Today, there are only about 270 such stations, most of them, unfortunately without a doctor. Although this is a strong claim, there has also been a drop in the demands of doctors' education (Beňová, 2018). The Government intends to address the problem of the outflow of educated doctors abroad by increasing the number of students admitted to the medical faculties of the Slovak universities. But is this an effective solution? Will this not only confirm the previous consideration? Why has this situation occurred and persisted? Is there not enough funding from the state budget, or is it the process of demotivating the workers? The Ministry of Health of the Slovak Republic also actually solve the situations that can affect both the conduct and behaviour of a person in the workplace, the quality of working environment, appropriate infrastructure, wage levels, sufficient cooperation with colleagues, trouble-free access to special work tools and equipment, self-development, etc. In October 2018, Minister of Health Kalavská stated that the next year's most important issue for the Ministry of Health (MZ) SR was to stabilize and recruit new workers to the sector. The ambition of this contribution is therefore to deal with the motivation and its selected aspects, but also its opposite, the inadequate motivation of medical staff in Slovakia. The subject of the study was the National Oncology Institute in Bratislava, Slovakia (hereinafter referred to as NOU), which is a specialized hospital focused on providing comprehensive oncology health care.

\section{Theoretical Background}

Over the past 5 years, 55 new anticancer drugs have been launched worldwide. Considering the increasing costs of innovative treatments, both the number and the relevance of costeffectiveness analyses has increased, which significantly supports decision making by stakeholders and policy makers. In particular, cost-effective treatments remain unavailable to patients because they are still unaffordable for many payers (Aguiar et al., 2019). The sources of funding for health systems may be taxes, health levies, supplementary health insurance or a combination of both. While taxes burden the labour factor (income from work), the consumption of individuals (excise duties and VAT) and their assets (property taxes), health levies and supplementary health insurance only affect the labour factor (income from work). However, there is no consensus on what resources can more effectively meet the needs of health systems (Morvay, 2013). The results in generating profits are a driving force behind the entry into the private healthcare business and the provision of services. However, nonfinancial motivations are also emphasised, such as efforts to serve the disadvantaged, personal ambition, desire for greater social status, obligations to continue family business and adverse family events (Adams et al., 2019). Psychologists have studied human motivation extensively and have formulated a variety of theories about what motivates people. Needsbased theories include Maslow's hierarchy of needs, Aldersfer's theory, Herzberg's two-factor 
theory and McClelland's acquired needs theory. Another approach focuses on external factors and their role in understanding employee motivation (e.g. Skinner's reinforcement theory). Theories based on intrinsic factors focus on internal thought processes and perceptions of motivation (e.g. Adam's theory of equity, Vroom's theory of expectations, Locke's theory of goal setting) (Buchbinder \& Shanks, 2007). Kuznecova (2012) also participated in the demotivation of workers, analysing the employee's attitude to the changes made by the management of the company based on the modelling method. The employee performance was analysed through the motivation. Marasová (2006) says that an enterprise must seek to find a partner and a co-worker within the employees who actively participate in meeting business goals. Both the position and the content of the motivation of the working person have been significantly changed recently. It is essential that the incentive policy of an enterprise wishing to survive an increasingly competitive environment adapt these changes. It can be specified in such motivating management that involves providing an ethical work environment. The health workforce has specific features that cannot be ignored, and motivation can play an integral role in many of the major health challenges today (Ratanawongsa et al., 2006). Healthcare organizations face external pressures that cannot be effectively managed without appropriate adjustments to the workforce and therefore the workforce development appears to be a key part of the health policy development process (Soltes \& Gavurova, 2014; Pavlas Martanová \& Frombergerová, 2018).

Several authors (e.g. Dieleman \& Kleinau, 2017), were examining the demotivation and motivation of healthcare professionals, they analyzed the satisfaction, work and motivation among Vietnamese healthcare staff). The results show that salaries and working conditions discourage public health workers in rural areas in Vietnam. Low salaries force them to earn extra income in other ways, even if they work in the private sector. According to Rodotis and Kefalidi (2016), the factors that affect the selection of Greek doctors' workplaces are many, such as: quality of working environment, wage increases, cooperation with competent colleagues, workload, city/village where they work, health personnel access to special equipment, professional standards, etc. According to Willis-Shattuck (2008), the lack of a properly trained and motivated workforce is a key obstacle to achieving health development goals. Hitka and Zámečník (2005) describe the possibility of analysing the enterprise's motivational environment using a questionnaire method and proposes a simple, timely, financially, technically unpretentious and operationally modifiable, transparent evaluation method. The authors developed a systematic overview of the consolidation of existing evidence of the impact of financial and non-financial incentives on motivation and retention. Brodský (2004) investigated whether managers are able and willing to use wellknown knowledge of motivational theories in their managerial work and whether there are differences between the public and profit sector in terms of employee motivation/demotivation. According to the study (Dieleman et al., 2003) motivation is influenced by both financial and nonfinancial incentives. The main motivating factors for healthcare professionals are the award of managers, colleagues and community, stable employment and income and training. The main demotivation factors related to low wages and difficult working conditions, but also to burnout.

Health professions are among the helping professions associated with increased professional stress, which may result in a burnout syndrome (Gazdíková, 2017). The causes of a burnout syndrome in healthcare professionals are: work with people, high demands, long-term negative balance of success and high responsibility. The occurrence of the burnout syndrome also affects, besides the profession, also the characteristics and assumptions of the individual personality, the influence of various risk factors on individual workplaces, professional focus, treatment methods, frequency of contacts with patients and other factors. In addition, warning signals are overlooked and underestimated by healthcare professionals themselves, which is related both to the peer-to-peer view of the status and occupation of a health professional, in particular a doctor, nurse, midwife, rescuer, etc., perceived as his/her whole life mission, but not "a normal job". There is also the fact that healthcare professionals are often afraid to express their own emotions, to seek help with work performance, as this gives rise to a sense 
of professional failure. The general approach is also reinforced by rescuers and by the idea of their vulnerability, extreme physical and mental exertion. The feeling is also known as "John Wayne syndrome". Burnout most often occurs in healthcare professionals working in oncology and psychiatric wards, in intensive care units, surgery, but also in patients with long-term illnesses. They are highly demanding in terms of professionalism, which, combined with great responsibility and personal commitment, leads to work in acute stress, constant readiness to help. The main trigger of the burnout are chronic stress, long-term pressure, high emotional tension, conflict of roles, lack of decision-making autonomy, insufficiently defined competencies and tasks, hazards in hierarchical structures, time-consuming work, mobbing at work. Burnout affects approximately $10 \%$ of people of working age, with health workers reporting a $12 \%$ prevalence of this syndrome. It is therefore essential to set realistic career goals, to allow enough time for rest and relaxation. Every healthcare professional must realize that he/she is primarily a person who also has his/ her own needs as well as certain limitations that need to be accepted. Only then he/she will be able to perform quality work without affecting his/her health.

Myšková (2005) defined the importance of efficient use of human resources in the context of workers' motivation by compiling a worker satisfaction indicator in several sectors. According to Mathauer and Imhoff (2006), healthcare professionals' specialized knowledge is generally strongly controlled and also some similar aspects related to professional ethos. In fact, many health care professionals are demoted and frustrated just because they are unable to satisfy their professional conscience. This prevents them from carrying out their profession due to a lack of resources and quality deliveries. In addition, insufficient or inappropriate human resources management tools are used. Gavurova and Soltes (2016) focused on research into development of daily health care in Slovakia. Major factors influencing the development of healthcare include a poorly adapted and economically inadequately motivated system that causes a significant lag in the European average. Similarly, the authors focus on both financial and non-financial aspects, with an emphasis on supporting day-to-day surgery support by public health care authorities as well as healthcare facilities and specialized medical facilities in order to improve patient satisfaction and motivation of healthcare professionals (Štefko et al., 2018). Mohelská and Sokolová (2015) as well as Myšková (2011) analysed the theoretical basis for organizational culture with the research question focused on the interdependence of organizational culture and leadership with potential impact on motivation of employees. They believe that employee satisfaction involves not only the efficient use of human resources but also the preservation and security of important business information. Satisfaction reduces staff fluctuations, positively affects productivity indicators and overall company performance. Authors Hitka and Blašková (2011) propose the creation of a system consisting of several subsystems: recognisance - survey/analysis of the level of internal motivation and its individual enhancement, identification of the use of professional and personal potential, mapping of the range of applied motivational tools, finding a measure of willingness to increase complex work performance, a job satisfaction survey and an work of organizations, and finding preferences/ideas for highly qualified human potential in this field.

In industrialized countries several studies have explored the importance of different goals and values for healthcare professional (see "US Evidence on Goals, Motives and Values in the Health Sector"), but there is only very limited and patchy evidence from developing countries. While there is a lack of evidence of what objectives and values are most important to healthcare professionals in developing countries, the conceptual framework suggests some important general points. First, work motivation is not a function of external factors, but is influenced by the interaction of these factors with unique personal factors, and therefore the results of the internal motivation process will vary among individuals in the same environment. In addition, due to the changing environmental factors, the individual's work motivation may also fluctuate over time or across situations (Bennett \& Franco, 2000). According to them, there are three levels of factors influencing the motivation of healthcare professionals namely, the individual level, the organizational level, and broader cultural and client influences. It is not possible to observe 
directly how these various factors influence the motivation of workers as motivation is an internal psychological process. In practice, a combination of individual and group motivation is often used leading to enterprise incentive programs that take into account the specificities of both the content and nature of the work activity as well as the specific professional and psychological prerequisites of the individuals and work groups that perform it. Work motivation cannot be observed or even measured. A certain idea can be obtained by measuring the expression of work motivation, for example by measuring employee performance or by examining a subjective indicator of employee satisfaction (Olexová \& Bosáková, 2006).

\section{Data and Methodology}

The aim of the paper is to investigate nonfinancial work motivation and to identify factors that affect employees in a selected medical facility, which was the National Oncology Institute in Bratislava, Slovakia (hereinafter referred to as NOU). The Institute provides specialized outpatient health care, specialized inpatient health care and intensive health care in relevant medical fields.

In 2017, 161 doctors, 290 nurses and 229 other workers were trained at the National Cancer Institute with 7,500 patients. The total area of the institute is $3,200 \mathrm{~m}^{2}$. In the spring of 2018, the Institute recorded employees who finished the job. Reasons why employees left were linked to several issues that the Institute had to fight with. All the reasons were contained in a letter sent to the management of the Institute. The main reason was the postponement of operations, which also involved an insufficient number of beds in the departments of the Institute. The lack of rooms for patients also increased due to the number of outgoing staffs to work abroad and several doctors in the wards, as evidenced by data indicating this. In 2018, the professionals in the Institute were 25\% lower than in 2017 (mainly administrative staff and nurses). Taking bribes in 2016 also contributed to the unfavourable atmosphere at the workplace. Employees also stated in the open letter that management lacked managerial skills and lacked knowledge of a specific cancer area. Employees asked for a transparent selection procedure and a public hearing of candidates with the publication of their institution management concept. These and many other "causes" led to the NOU being researched on the motivation of its employees.

We chose a questionnaire as the basic method of obtaining data from respondents. The questionnaire was preceded by the hypothesis. The questions in the questionnaire were formulated by selecting a specific answer and determining the importance of the Likert scale from 1 to 5 . This scale was an agreement or disagreement between the respondents and the question. The questionnaire was distributed among employees using the Google application form. It consisted of two parts. The first part of the questionnaire was identification. These were closed questions in which we verified the respondents' demographics. Demographic data included the respondent's gender and age, educational and the type of job in the facility. The second part of the questionnaire consisted of research questions focused on the factors that motivate/demotivate the employees at the place of their work. Respondents were asked about adequate working conditions, level of human relationships, or sufficient support for education and professional growth.

The questionnaire was designed for a total of 272 respondents, and we chose them by simple random selection by drawing lots. Questionnaires from the questionnaire survey were answered by 110 respondents working in the aforementioned medical facility. The return rate of the questionnaires was $24.44 \%$. For the survey, a return of about $25 \%$ can be considered very well and the results obtained can be considered relevant. An important part of our research was the hypotheses based on the main objective of the paper:

H1: We assume that there are statistically significant differences in male-female work motivation.

H2: We assume that there are statistically significant differences in motivation to stay at work.

H3: We assume that there are statistically significant differences in working demotivation between age categories.

Methods of statistical research (descriptive statistics, contingency tables, etc.) were used to evaluate acquired data using analysis, comparison, synthesis, selection, induction and deduction. Mathematical - statistical methods of Pearson's Chi-squared test and Mann-Whitney $U$ test were used to verify the hypotheses. 


\section{Tab. 1: Calculation of the selected indicators}

\begin{tabular}{|c|c|c|}
\hline Indicator & Formula & Explanatory note \\
\hline $\begin{array}{l}\text { Pearson's } \\
\text { Chi-squared test } \\
\text { of Independence }\end{array}$ & $x^{2}=\sum \frac{\left(f_{e}-f_{t}\right)^{2}}{f_{t}}$ & $\begin{array}{l}\mathrm{X}^{2}-\text { the Chi-square value subsequently compared } \\
\text { to a table value based on the selected error } \\
\text { probability; } \\
\mathrm{f}_{\mathrm{e}} \text { - the empirical frequency of observed variables; } \\
\mathrm{f}_{\mathrm{t}} \text { - the theoretical frequency of observed variables. }\end{array}$ \\
\hline Mann-Whitney U test & $\begin{array}{l}U_{1}=R_{1}-\frac{n_{1}\left(n_{1}+1\right)}{2} \\
U_{2}=R_{2^{-}} \frac{n_{2}\left(n_{2}+1\right)}{2}\end{array}$ & $\begin{array}{l}U_{1}-\text { the sum of the ranks achieved by the hares; } \\
U_{2}-\text { the sum of the ranks achieved by the hares; } \\
R_{1} \text { - the sum respectively associated values of } X ; \\
R_{2}-\text { the sum respectively associated values of } Y ; \\
n-\text { the number of observations in the sample. }\end{array}$ \\
\hline
\end{tabular}

Source: Marcheová, Tirpáková and Stehlíková (2011)

Pearson's Chi-squared is based on the study of dependence between variables. Dependency is based on the value of the correlation coefficient. The correlation coefficient is taken from -1 to +1 . When the value approximates to 1 , the dependence is stronger. We verified the first hypothesis through the Mann-Whitney $U$ test, which is a nonparametric test. It does not compare the averages, but compares the amounts in the order of options considered. To verify hypotheses, we used the statistical software SPSS from the StatSoft software company version 5.5 edition.

\section{Results}

The research we conducted in the selected healthcare facility was focused on work motivation and factors that demotivate employees at work. In this chapter, we have evaluated the primary data.

To determine work motivation, we predicted that there were statistically significant differences in the level of work motivation between women and men. The responses to the questionnaire were processed and plotted in Fig. 1.

\section{Fig. 1: Work motivation}

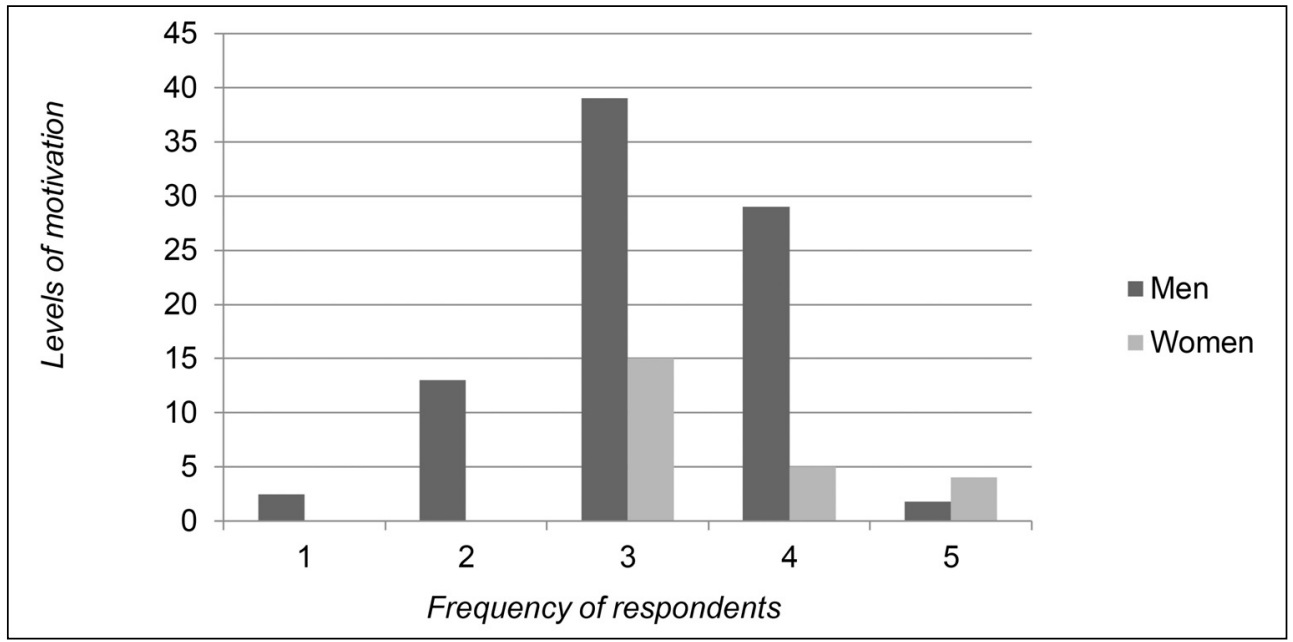




\begin{tabular}{l|c}
\multicolumn{1}{c|}{ Indicator } & Level of motivation \\
\hline Mann-Whitney U test & 844.000 \\
\hline Wilcoxon W & $4,585.000$ \\
\hline Z & -1.475 \\
\hline Asymp. Sig. (2-tailed) & 0.140 \\
\hline
\end{tabular}

Source: own according to statistical program SPSS

Based on the responses we received from the questionnaire, we focused on the gender ratios of each category and the established alternative hypotheses.

HO: There are no significant differences between the analysed variables in the surveyed issue.

H1: Significant differences exist between the analysed variables in the examined issue.

Based on the p-value (0.140), that is greater than 0.05 , we reject the alternative $\mathrm{H} 1$ hypothesis and accept the hypothesis $\mathrm{HO}$ with the position that there are no significant differences between the analysed variables in the examined issue. Based on this argument, we reject our basic hypothesis that there are statistically significant differences in the level of work motivation between women and men. At the same time, we believe that there is no statistically significant difference between the age categories in terms of employee motivation. Therefore, we do not accept the hypothesis.

Another hypothesis was focused on differences in reasons of work of employees among in age categories. We processed the answers from the questionnaire and presented the results in Fig. 2.

\section{Fig. 2: Reasons why employees remain working in the facility}

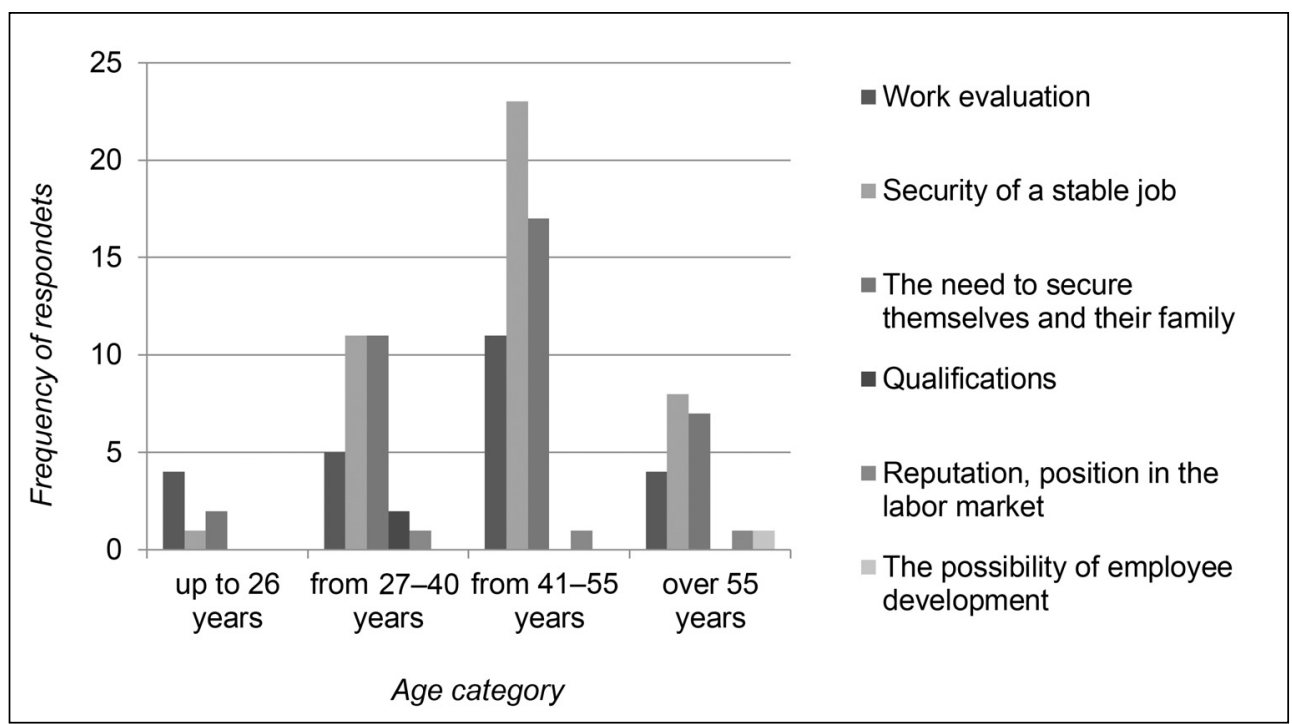




\section{Numerical statement of reasons}

\begin{tabular}{c|c|c|c|c|c|c|c}
\multicolumn{2}{c|}{ The reason employees remain working in the company } \\
\multicolumn{2}{|c}{ Age category } & $\begin{array}{c}\text { Work } \\
\text { evaluation }\end{array}$ & $\begin{array}{c}\text { Security of } \\
\text { a stable job }\end{array}$ & $\begin{array}{c}\text { Need to } \\
\text { secure } \\
\text { themselves } \\
\text { and family }\end{array}$ & Qualifications & $\begin{array}{c}\text { Reputation, } \\
\text { position in } \\
\text { the labor } \\
\text { market }\end{array}$ & $\begin{array}{c}\text { Possibility } \\
\text { of employee } \\
\text { development }\end{array}$ \\
\hline \multirow{2}{*}{ Up to 26 years } & No. & 4 & 1 & 2 & 0 & 0 & 0 \\
\cline { 2 - 8 } & $\%$ & $57.1 \%$ & $14.3 \%$ & $28.6 \%$ & $0.0 \%$ & $0.0 \%$ & $0.0 \%$ \\
\hline \multirow{2}{*}{$27-40$ years } & No. & 5 & 11 & 11 & 2 & 1 & 0 \\
\cline { 2 - 8 } & $\%$ & $16.7 \%$ & $36.7 \%$ & $36.7 \%$ & $6.7 \%$ & $3.3 \%$ & $0.0 \%$ \\
\hline \multirow{2}{*}{$41-55$ years } & No. & 11 & 23 & 17 & 0 & 1 & 0 \\
\cline { 2 - 8 } & $\%$ & $21.2 \%$ & $44.2 \%$ & $32.7 \%$ & $0.0 \%$ & $1.9 \%$ & $0.0 \%$ \\
\hline \multirow{2}{*}{ Over 55 years } & No. & 4 & 8 & 7 & 0 & 1 & 1 \\
\cline { 2 - 8 } & $\%$ & $19.0 \%$ & $38.1 \%$ & $33.3 \%$ & $0.0 \%$ & $4.8 \%$ & $4.8 \%$ \\
\hline \multirow{2}{*}{ Total } & No. & 24 & 43 & 37 & 2 & 3 & 1 \\
\cline { 2 - 8 } & $\%$ & $21.8 \%$ & $39.1 \%$ & $33.6 \%$ & $1.8 \%$ & $2.7 \%$ & $0.9 \%$ \\
\hline
\end{tabular}

Source: own

Based on the above graph, where we focused on the ratios of the individual categories between the age and the numerical expression of the results, we present Tab. 3 .

From the answers obtained from the questionnaire, we focused on the ratios of each category between genders and established alternative hypotheses. The results of the Pearson's Chi-squared test are shown in Tab. 4.

HO: There are no significant differences between the analysed variables in the examined issue.

H1: Significant differences exist between the analysed variables in the examined issue.

Based on the p-value (0.359), which is greater than 0.05 , we reject the alternative hypothesis $\mathrm{H} 1$ and accept the hypothesis $\mathrm{H} 0$ with the position, there are no significant differences between the analysed variables in the examined issue. Based on this argument, we reject our basic hypothesis $\mathrm{H} 2$ and believe that there is no statistically significant difference between age categories as a reason for employee to work. We do not accept the hypothesis.

The second hypothesis examined the differences in working demotivation between the age categories. The responses from the questionnaire were processed and graphically depicted on the Fig. 3. First, it was necessary to identify the order of motivation/demotivation factors identified by the employees themselves.

The respondents themselves, regardless of their age, are most rated by their work. Demographic evaluation of the work was reported by $35.5 \%$ of the respondents, which is in the absolute number of 39 respondents. Insufficient financial and non-financial factors were mentioned as demotivation when evaluating their performance. Non-financial factors included written praise from employees, as well as thanks, interview with management, and other activities that might bring employees closer. Similarly, Tumble Research, Jeringan and Kohut (1995), states that, for example, more than $50 \%$ of the nurses surveyed classified as being 'morally committed' work compared to $12 \%$ who were committed to their employer only for the material benefits they had from the relationship. Another study found that recognition, work itself, and responsibility were the main motivating factors in the nursing profession. The most de-motivated with the evaluation of their work in our research are employees aged 20 to 40 years. Another demotivating factor reported by 29 respondents, or $26.4 \%$, is related to insufficient 


\begin{tabular}{l|c|c|c} 
& Value & $\begin{array}{c}\text { Df (degree } \\
\text { of freedom) }\end{array}$ & Asymptotic significance (2-sided) \\
\hline Pearson's Chi-squared Test & 16.351 & 15 & 0.359 \\
\hline $\mathrm{N}$ of valid cases & 110 & & \\
\hline
\end{tabular}

working conditions. These working conditions most demotivate employees aged 41 to 55 . Insufficient working conditions were facilities for the employees themselves (changing rooms). For less demotivating factors, 22 respondents believe that the level of management motivation on the healthcare facility is low, which is $20 \%$. The employee equipment does not provide appropriate forms of incentive programs. 11 respondents $(10 \%)$ reported demotivating bad working relationships in the workplace, which was also reflected in last year's medical leave. Also, de-motivating, but to a lesser extent, respondents reported low levels of career growth, weak opportunities for business education, a lot of bureaucratic work, but also a communication system. Less than $9 \%$ of respondents ranked these factors as demotivating. Clear communication of the objectives and the rationale for the reform is necessary to help ensure the recognition of objectives between healthcare professionals, and to help prevent demotivation by assuring and reducing the level of uncertainty.

For the numerical expression of the results, we present Tab. 5 .

Based on the responses we received from the questionnaire, we focused on the gender ratios of each category and established alternative hypotheses. We offer the results of the Pearson's Chi-squared test in Tab. 6.

HO: There are no significant differences between the analysed variables in the examined issue.

\section{Fig. 3: Types of demotivation at the workplace}

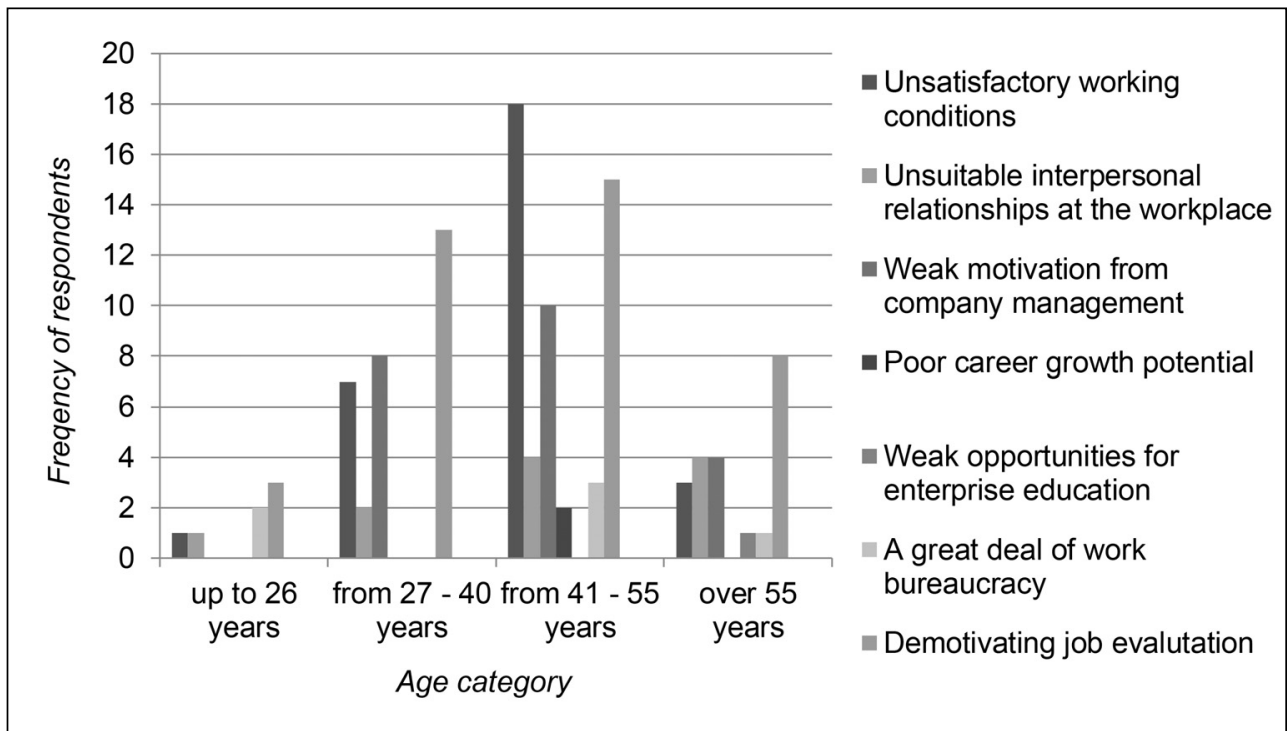




\section{Tab. 5: Numerical statement of reasons}

Types of demotivation at the workplace

\begin{tabular}{|c|c|c|c|c|c|c|c|c|}
\hline \multicolumn{2}{|c|}{ Age category } & 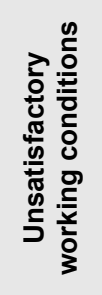 & 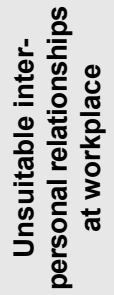 & 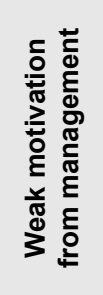 & 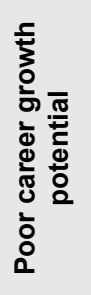 & 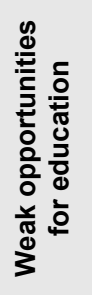 & 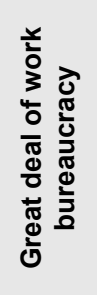 & 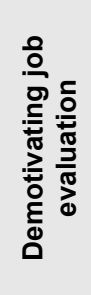 \\
\hline \multirow{2}{*}{$\begin{array}{c}\text { Up to } \\
26 \text { years }\end{array}$} & No. & 1 & 1 & 0 & 0 & 0 & 2 & 3 \\
\hline & $\%$ & $14.3 \%$ & $14.3 \%$ & $0.0 \%$ & $0.0 \%$ & $0.0 \%$ & $28.6 \%$ & $42.9 \%$ \\
\hline \multirow{2}{*}{$27-40$ years } & No. & 7 & 2 & 8 & 0 & 0 & 0 & 13 \\
\hline & $\%$ & $23.3 \%$ & $6.7 \%$ & $26.7 \%$ & $0.0 \%$ & $0.0 \%$ & $0.0 \%$ & $43.3 \%$ \\
\hline \multirow{2}{*}{$41-55$ years } & No. & 18 & 4 & 10 & 2 & 0 & 3 & 15 \\
\hline & $\%$ & $34.6 \%$ & $7.7 \%$ & $19.2 \%$ & $3.8 \%$ & $0.0 \%$ & $5.8 \%$ & $28.8 \%$ \\
\hline \multirow{2}{*}{$\begin{array}{c}\text { Over } 55 \\
\text { years }\end{array}$} & No. & 3 & 4 & 4 & 0 & 1 & 1 & 8 \\
\hline & $\%$ & $14.3 \%$ & $19.0 \%$ & $19.0 \%$ & $0.0 \%$ & $4.8 \%$ & $4.8 \%$ & $38.1 \%$ \\
\hline \multirow{2}{*}{ Total } & No. & 29 & 11 & 22 & 2 & 1 & 6 & 39 \\
\hline & $\%$ & $26.4 \%$ & $10.0 \%$ & $20.0 \%$ & $1.8 \%$ & $0.9 \%$ & $5.5 \%$ & $35.5 \%$ \\
\hline
\end{tabular}

H1: There are significant differences between the variables analysed in the issue under investigation.

Based on Pearson, whose value (0.16) is greater than 0.05 , we reject the alternative hypothesis $\mathrm{H} 1$ and accept the hypothesis $\mathrm{HO}$ with the position, there are no significant differences between the analysed variables in the examined issue. Based on this argument, we reject our basic hypothesis $\mathrm{H} 2$, and we believe that there is no statistically significant difference between age categories in employee demotivation. We also note that the calculation was performed on a relatively low numbered set in several categories, so we interpret the output carefully to accept the hypothesis.

\section{Discussion and Conclusions}

The starting point for how to effectively motivate co-workers is above all knowledge of the motivation process, knowledge of what motivates people, knowledge of their individual needs, interests, values and aspirations. The work performance and work behaviour of an employee depends on his/her acceptance of the organization's objectives, understanding their role, their readiness to fulfil these tasks (knowledge, skills, experience), their willingness to perform the tasks best, their motivation, and under which the task is accomplished. From the above ideas and from experience it is possible to determine two types of stimuli or motives - external and internal. As part of external incentives, we recommend fair pay, job security, working conditions, or social benefits. Internally, we are motivated by the need to do work that satisfies us, the need for improvement, personal values, aspirations and ideals. Many motivational studies prove that the financial rewards (salary or profit shares are by no means the only important motivating factor. This was confirmed by our research. The database of questionnaire responses was in practical part analysed by statistical methods Pearson's Chi-squared, Mann-Whitney U, Wilcoxon W, $Z$ and Asymp. Sig. (2-tailed). The purpose of the questionnaire was to determine the attitude of respondents to their performance at work, the working environment, and interpersonal 
Tab. 6: Results of Pearson's Chi-squared test

\begin{tabular}{l|c|c|c} 
& Value & Df & $\begin{array}{c}\text { Asymptotic significance } \\
\text { (2-sided) }\end{array}$ \\
\hline Pearson's Chi-squared test & 23.853 & 18 & 0.16 \\
\hline N of valid cases & 110 & & \\
\hline
\end{tabular}

Source: own

relationships in the context of non-financial de-motivation. We used the detailed statistical analysis and we tested three hypotheses, two of which we have not accepted and one has been accepted. The results of these sub-hypotheses are the subject of the very chapter, where we tested them. In the questionnaire survey, we also received information from respondents related not only to the de-motivating but also to the motivating factors of the respondents in their healthcare facility. However, it was essential to find out demotivation factors based on which the individual employees have a negative relation to the actual performance of work in a health facility or to the interpersonal relationships in the workplace. The most important factors mentioned by respondents in their responses are poor employee appraisal, either in the form of wages, but above all in praise, rewards and recognition in the workplace not only from the top facility management, but also from direct supervisors in the workplaces and the employees themselves. Equally important are demotivating factors, the respondents stated insufficient motivation management activities that create space only for demotivating respondents.

Not only the basic working conditions of the work are considered to be not satisfactory, but also the air conditioning of the room (hot summer, cold winter), frequent repetitive work shifts of respondents, are also inappropriate for employees. All these demotivating factors led respondents to leave certain workplaces in the facility and they refused to do the required work performance in a workplace of the healthcare facility.

The research has also shown that managers and workers do not necessarily perceive motivation in the same way. Therefore, we encourage managers to clearly understand employee requirements. According to Dieleman et al. (2003), we can also confirm as many managers believe that an increase in salaries will solve the motivation problems, it is important to understand that, while important, improving payments will not be sufficient to achieve sustainable better performance. The study showed that motivation is influenced by both financial and non-financial incentives. The main motivating factors for healthcare professionals were when managers, colleagues and the community expressed gratitude for work, then a stable job, income and training. The main discouraging factors were low wages and difficult working conditions. In order to improve motivation and thereby increase staff performance, attention should be paid to motivation factors, for example by increasing the individual's sense of success and showing recognition of that achievement.

- In the future, we recommend conducting research in areas, such as:

- Comparison of the motivation system in healthcare with other areas/resorts of economic and social life. Unlike the primary sphere, healthcare has workplaces requiring equipment that is not cheap (with an extremely long depreciation period) and the need to finance its operation, as well as the means to receive special training. The problem with the motivation system is also in poorly funded health care. Therefore, it would be appropriate not to study motivation systems specifically, but in individual comparative aspects.

- Comparison of the motivation system in healthcare facilities in individual selfgoverning regions due to possible disproportions. Healthcare business runs on a long track. It has an important aspect of social responsibility that this sector carries. Health care is provided free of charge to all residents. However, disadvantaged regions believe that this is lacking due to a shortage of doctors and medical staff. How to motivate healthcare professionals not to fluctuate, but to stop in all self-governing 
regions adequately to their needs? This could be the subject of further research.

- Research on communication and leadership in healthcare. Healthcare or healthcare work is always teamwork. There are more than twenty professions that doctors need to work together through nurses, lab technicians, sanitarians, physiotherapists, etc. These people working in this system, must have clearly defined activities that they can do with suggestions (e.g. their education) and must already be redirected to another healthcare professional. However, this can only be done on the basis of functioning communication in a wellorganized organizational structure.

In our research, we see limits and restrictions in the facility surveyed which was limited to only one medical facility. In our research, we profiled only a specific area because we were interested in the results in the aforementioned healthcare facility. It is possible that when selecting another object the results would be different, but we responded to the current situation presented also in the professional public. It is these limits that prompted us to focus our future research in which we would continue to explore the issue of employee motivation and demotivation in other areas of healthcare.

\section{References}

Adams, A. M., Ahmed, R., Shuvo, T., Yusuf, S. S., Akhter, S., \& Anwar, I. (2019). Exploratory qualitative study to understand the underlying motivations and strategies of the private for-profit healthcare sector in urban Bangladesh. BMJ Open, 9(7), e026586. https://doi.org/10.1136/bmjopen-2018-026586

Aguiar, P. N., Roitberg, F., Noia Barreto, C., Adashek, J. J., Del Giglio, A., \& Lopes, G. L. (2019). Back to the Future: In the Era of CostEffectiveness Analysis, Affordability Is a Limiting Factor for Patients' Access to Innovative Cancer Treatments. Value in Health Regional Issues, 20, 40-57. https://doi.org/10.1016/j. vhri.2018.12.003

Beňová, Z. (2018). Na Slovensku je kritický nedostatok lekárov. Retrieved February 25, 2019, from https://spravy.pravda.sk/domace/ clanok/458237-na-slovensku-je-kritickynedostatok-lekarov/

Buchbinder, S., \& Shanks, N. (2007). Introduction to Health Care Management. Sudbury: Jones and Bartlett Publishers.
Bennett, S., \& Franco, L. M. (2000). Health Worker Motivation and Health Sector Reform. Bethesda, MD: PHR Primer.

Brodský, Z. (2004). Psychologické a sociologické aspekty $\vee$ managementu. $E \& M$ Economics and Management, 7(3), 42-46.

Dieleman, M., \& Kleinau, E. (2017). Factors influencing retention, job satisfaction, and motivation among Jordanian health workers. Annals of Global Health, 83(1), 51-52. http://doi.org/10.1016/j.aogh.2017.03.112

Dieleman, M., Cuong, P. V., Anh, L. V., \& Martineau, T. (2003). Identifying factors for job motivation of rural health workers in North Viet Nam. Human Resources for Health, 1(10), 10. https://doi.org/10.1186/1478-4491-1-10

Gavurova, B., \& Soltes, M. (2016). System of day surgery in Slovakia: analysis of pediatric day surgery discrepancies in the regions and their importance in strategy of its development. E\&M Economics and Management, 19(1), 74-92. https://doi.org/10.15240/tul/001/2016-1-006

Gazdíková, K. (2017). Syndróm vyhorenia u zdravotníckych pracovníkov. Via practica, 14(4), 178-185.

Hitka, M., \& Blašková, M. (2011). Model riadenia pracovnej motivácie $v$ priemyselných podnikoch. Zvolen: Technická univerzita vo Zvolene.

Hitka, M., \& Zámečník, R. (2005). Diagnostikovanie motivačního prostredia robotníkov v ŽOS, a.s. Zvolen. E\&M Economics and Management, 8(3), 60-65.

Kuznecová, E. (2012). Demotivacija personala: prichiny, fakotry, metody ustranenija. Sovremennye issledovanija social'nyh problém, 11(19).

Marasová, J. (2006). Motivácia a tvorivost' zamestnancov $\mathrm{v}$ rozvoji podniku. E\&M Economics and Management, 9(2), 43-48.

Marcheová, D., Tirpáková, A., \& Stehlíková, B. (2011). Základy štatistiky pre pedagógov. Nitra: Univerzita Konštantína Filozofa v Nitre.

Mathauer, I., \& Imhoff, I. (2006). Health worker motivation in Africa: the role of nonfinancial incentives and human resource management tools. Human resources for health, 4(24). https://doi.org/10.1186/14784491-4-24

Mohelská, H., \& Sokolová, M. (2015). Organisational culture and leadership-joint vessels? Procedia-Social and Behavioral Sciences, 171, 1011-1016. https://doi. org/10.1016/j.sbspro.2015.01.223 
Morvay, K. (2013). Zdravotníctvo, trhy, regulácia, politika. Bratislava: Health Policy Institute.

Myšková, R. (2005). Metodika hodnocení spokojenosti pracovníků. E\&M Economics and Management, 8(1), 97-103.

Myšková, R. (2011). A New Measure of Employee Satisfaction. Global Journal of Business Research, 5(1), 101-110.

Nakonečný, M. (1992). Motivace pracovního jednání. Praha: Management Press.

Olexová, C., \& Bosáková, M. (2006). Motivácia a spokojnost' zamestnancov. Personálny a mzdový poradca podnikatela. 184-192.

Pavlas Martanová, V., \& Frombergerová, A. (2018). Evaluation of a Czech Adaptation of the Boys and Girls Plus Prevention Programme. Adiktologie, 18(3), 189-197.

Ratanawongsa, N., Howell, E. E., \& Wright, S. M. (2006). What motivates physicians throughout their careers in medicine? Comprehensive Therapy, 32(4), 210-217. https://doi.org/10.1007/BF02698065

Robbins, S. P. (2001). Organizational Behavior (9th ed.). Upper Saddle River, NJ: Prentice Hall.
Rodotis, K., \& Kefalidi, I. (2016). How do Greek junior doctors perceive their professional future? World Medical Association Junior Doctor Network, 6-7.

Stefko, R., Gavurova, B., \& Kocisova, K. (2018). Healthcare efficiency assessment using DEA analysis in the Slovak Republic. Health Economics Review, 8(1), 475-485. https://doi. org/10.1186/s13561-018-0191-9

Soltes, M., \& Gavurova, B. (2014). Identification of the Functionality Level of Day Surgery in Slovakia. Ekonomický časopis, 62(10), 1031-1051.

Tumulty, G., Jernigan, I. E., \& Kohut, G. (1995). Reconceptualizing organizational commitment. Journal of Nursing Administration, 25(1), 61-65.

Willis-Shattuck, M., Bidwell, P., Thomas, S., Wyness, L., Blaauw, D., \& Ditlopo, P. (2008). Motivation and retention of health workers in developing countries: a systematic review. BMC health services research, 8(1), 247-254. https://doi.org/10.1186/1472-6963-8-247 